\title{
PENGARUH PERUBAHAN KOMPOSISI KEPEMILIKAN SAHAM SEBAGAI AKIBAT STOCK SPLIT TERHADAP LIKUIDITAS SAHAM
}

\author{
Nuri Lesmono Hidayah, \& Harits Noordin \\ Akademi Perikanan Yogyakarta, Indonesia \\ Email: nuri_lesmono@yahoo.com
}

\begin{abstract}
Abstrak: Pengaruh Perubahan Komposisi Kepemilikan Saham Sebagai Akibat Stock Split terhadap Likuiditas Saham. Penelitian ini bertujuan untuk mengetahui dampak pemecahan saham terhadap perdagangan saham di Bursa Efek Indonesia (BEI) dengan memperhatikan komposisi kepemilikan saham. Komposisi kepemilikan saham publik dan perubahannya dalam kegiatan stock split diduga memiliki pengaruh terhadap likuiditas saham. Populasi penelitian ini adalah seluruh perusahaan di Bursa Efek Indonesia. Sampel penelitian sebanyak 48 perusahaan yang melakukan stock split pada periode 2010 - 2015. Pemilihan sampel menggunakan metode purposive sampling. Metode pengujian hipotesis menggunakan metode paired sampled t test dan analisis regresi. Hasil penelitian ini menunjukkan bahwa peristiwa stock split memberikan dampak terhadap perdagangan saham. Stock split menyebabkan terjadinya perbedaan yang signifikan dari cumulative abnormal return (CAR) dan ratarata trading volume activity sebelum pemecahan saham dibandingkan setelah pemecahan saham. Berkenaan dengan komposisi saham publik dan perubahannya dalam peristiwa stock split ternyata tidak berpengaruh terhadap likuiditas perdagangan saham.
\end{abstract}

Kata kunci: pemecahan saham, likuiditas, kepemilikan publik

\begin{abstract}
The Effect of Change in Stock Ownership because of Stock Split on Stock Liquidity. This study aimed to determine the effect of the stock split on stock trading by considering stock ownership proportion in companies listed in the Indonesian Stock Exchange (IDX). This study hypotesized that stock ownership proportion and its change in later date affected stock liquidity. The population of this study was companies in the Indonesia Stock Exchange. The samples were 48 companies which conducted stock split in 2010-2015. The sample was selected by purposive sampling method. Hypotesis was tested by using paired sampelled t-test and regression analysis. The study found that stock split indeed affected stock trading. Stock split significantly affected Cumulative Abnormal Return (CAR) and trading activity, compared to data before stock split occurred. However, the studi also found that stock ownership proportion and its changes in later date did not affect stock liquidity.
\end{abstract}

Keywords: stock split, liquidity, public shareholder

\section{PENDAHULUAN}

Pasar modal di Indonesia berkembang sebagai salah satu pilihan bagi perusahaan untuk mendapatkan dana dari masyarakat. Saham sebagai salah satu intrumen yang diperdagangkan memberikan gambaran kondisi perusahaan tersebut. Pasar modal yang efisien akan menerima informasi perusahan yang masuk ke pasar modal dan akan bereaksi sehingga akan terjadi keseimbangan harga saham. Investor menggunakan informasi yang relevan berkenaan dengan faktor interal dan eksternal perusahaan dalam pengambilan keputusannya. Informasi-informasi Kegiatan perusahaan baik rutin maupun insidental 
menjadi perhatian para investor dalam memperkirakan pergerakan saham dimasa yang akan datang.

Pergerakan saham di bursa menunjukkan fluktuasi perubahan harga saham sebagai akibat transaksi perdagangan. Informasi harga saham menjadi salah satu pertimbangan investor dalam melakukan pemilihan saham-saham yang akan menjadi pilihan investasinya. Investor cenderung memilih saham-saham yang memiliki harga yang mencerminkan nilai perusahaan secara wajar atau bahkan underprice. Harga saham yang dianggap underprice mendorong para investor untuk membeli saham tersebut dengan harapan harga saham tersebut akan terkoreksi dimasa yang akan datang. Apabila suatu saham harganya dinilai terlalu tinggi (overprice) maka jumlah permintaan akan saham tersebut akan berkurang dan sebaliknya banyak investor akan berusaha menjual saham mereka. Penilaian investor terhadap kewajaran harga suatu saham yang berbeda akan mendorong terjadinya perdagangan dan keseimbangan penawaran dan permintaan saham. Harga saham yang dinilai terlalu mahal oleh investor (overprice) akan mengurangi minat konsumen untuk membeli saham tersebut. Untuk menarik minat investor, perusahaan perlu mempertahankan harga saham mereka pada rentang yang wajar dan ideal menurut para investor.

Kebijakan perusahaan dalam meningkatkan likuiditas saham mereka di bursa saham adalah dengan mengelola harga saham perusahaan mereka sehingga menarik para investor untuk memiliki saham tersebut dan melakukan transaksi perdagangan. Perusahaan berusaha menyesuaikan harga sahamnya dengan penilaian yang dilakukan oleh investor terhadap kondisi perusahaan. Pemecahan saham (stock split) merupakan salah satu strategi perusahaan dalam rangka menyesuikan harga sahamnya sesuai dengan rentang harga yang dianggap wajar dan affordable bagi investor. Strategi stock split untuk menata ulang harga saham suatu perusahaan agar sesuai dengan rentang harga yang wajar bagi investor menjadi pilihan yang banyak dilakukan oleh perusahaan di Bursa Efek Indonesia. Peristiwa stock spli tyang sering terjadi dalam perusahaan tersebut mengindikasikan bahwa strategi stock split saham merupakan salah satu alternatif yang dipandang cocok oleh perusahaan-perusahaan di Indonesia. Stock split dikategorikan sebagai suatu peristiwa yang dapat dilakukan oleh perusahaan dalam rangka untuk memengaruhi keputusan investasi pemodal dalam pengambilan keputusan pembelian melalui keberadaan harga yang affordable. Peristiwa stock split menyebabkan terjadinya perubahan nilai nominal saham, nilai pasar saham, dan jumlah saham yang beredar.

Pemecahan saham hanya melibatkan penambahan jumlah saham yang beredar dan penyesuaian harga nominal per lembar saham sehingga seharusnya tidak signifikan merubah nilai kapitalisasi saham yang beredar di masyarakat. Pemecahan saham tidak akan memberikan dampak secara langsung bagi perusahaan dalam penambahan arus kas sebagai akibat pemecahan saham. Oleh karena itu, pemecahan saham seharusnya tidak memiliki nilai ekonomis bagi perusahaan secara langsung dan tidak berpengaruh pada nilai kekayaan perusahaan. Walaupun 
demikian, banyak perusahaan di Indonesia yang masih melakukan pemecahan saham mereka, sehingga tindakan ini merupakan tindakan penting dalam praktik pasar modal di Indonesia (Haryanto \& Hermawan, 2005).

Penelitian terdahulu banyak memberikan hasil dan kajian pustaka tentang kegiatan stock split. Kegiatan stock split menjadi tindakan perusahaan yang menarik untuk dicermati karena terdapat pandangan beragam mengenai motivasi perusahaan melakukan stock split. Pendapat pertama menyatakan bahwa stock split merupakan corporate action yang sifatnya adalah administratif dan penyesuaian harga yaitu upaya membuat harga saham agar tampak lebih menarik di mata investor, di mana tindakan ini hanya menyebabkan perubahan akuntansi lewat pengurangan par value sehingga tidak signifikan mengubah jumlah modal di neraca sehingga tidak mengubah kekayaan perusahaan (Sukardi, 2000:24). Tindakan stock split menimbulkan efek fatamorgana saja di mana investor seolaholah menjadi lebih makmur karena memegang lembar saham dalam jumlah lebih banyak. Padahal penambahan lembar saham yang dimiliki juga diiringi dengan penurunan nilai per lembar saham.

Penelitian dengan simpulan berbeda berkenaan stock split menyatakan bahwa kegiatan stock split yang dilakukan perusahaan mampu memberikan sinyal kepada investor bahwa kondisi perusahaan menjadi lebih prospektif dan menarik. Penelitian Anggraini \& Jogiyanto (2000) menunjukkan bahwa stock split membawa informasi dividen kas. Informasi ini dapat digunakan investor untuk pengambilan keputusan tentang kondisi perusahaan.
Pelaksanaan stock split mengakibatkan harga saham menjadi lebih rendah dan memberikan pengaruh pada faktor likuiditas saham tersebut di pasar modal.

Penelitian - penelitian terdahulu yang dilakukan mengenai kegiatan stock splityang dilakukan perusahaan tersebut memperlihatkan hasil yang beragam dan tidak konsisten. Beberapa hasil penelitian menunjukkan dan membuktikan bahwa stock split berpengaruh terhadap variabel harga dan likuiditas saham.Beberapa penelitan yang mendukung keberadaan pengaruh stock split terhadap pasar antara lain dilakukan oleh Fatmawati \& Asri (1999); Anggraini \& Jogiyanto (2000); Asquith dan Hartono (2003). Namun di sisi lain, beberapa penelitian memberikan kesimpulan bahwa stock split tidak memberikan pengaruh terhadap pasar. Margaretha mengindikasikan bahwa pasar tidak bereaksi dengan adanya stock splittidak ada perbedaan signifikan rata-rata volume perdagangan saham sebelum dan sesudah pengumuman stock split.

Penelitian Fatmawati \& Asri (1999) menyimpulkan bahwa stock split berpengaruh signifikan terhadap harga saham, volume perdagangan dan persentase spread. Hasil penelitian Anggraini \& Jogiyanto (2000) menunjukkan bahwa stock split membawa informasi dividen kas. Dampak stock split terhadap keuntungan investor juga dijelaskan oleh Grinblatt, Masulis \& Titman (1984) yang menyatakan bahwa di pengumuman stock split mengakibatkan adanya perilaku harga saham yang abnormalyang dilakukan oleh para investor disekitar periode pelaksanaan stock split. 
Banyak peneliti melakukan penelitian berkenaan dengan stock split dengan likuiditas saham. Lin, Yu \& Singh (2008) melakukan penelitian tentang pengaruh pemecahan saham terhadap peningkatan kecepatan perdagangan saham. Hasil penelitian mereka menyatakan bahwa pemecahan saham akan membuat saham lebih dapat dijangkau oleh investor kecil, dan pemecahan saham akan meningkatkan kecepatan perdagangan saham tersebut walaupun biaya transaksi menjadi lebih mahal. Menurut mereka, faktor kesulitan memperjualbelikan saham karena kemahalan harga menjadi salah satu faktor dalam melakukan pemecahan saham. Dengan pemecahan saham, harga saham menjadi lebih murah dan dapat dijangkau investor kecil. Walaupun biaya transaksi akan menjadi lebih mahal, namun karena kecepatan perdagangan saham meningkat, maka kemahalan biaya transaksi dapat tertutupi dengan adanya peningkatan kecepatan perdagangan saham tersebut.

Pemecahan harga saham menjadi lebih rendah memberikan pengaruh pada faktor likuiditas saham tersebut di pasar modal. Pemecahan saham bermanfaat terhadap peningkatan likuiditas saham tersebut. Hal ini terjadi karena pemecahan saham akan menurunkan harga saham dan akan membuat saham lebih menarik bagi investor kecil dan lebih dapat dijangkau untuk melakukan pembelian. Pendapat ini juga didukung oleh Sutrisno, Susilowati \& Yuniartha (2000) yang menyatakan bahwa pemecahan saham akan mengembalikan harga saham pada titik optimal perdagangan sehingga akan meningkatkan likuiditas perdagangan saham tersebut. Lebih lanjut penelitiannya menyatakan bahwa perusahaan yang melakukan pemecahan saham akan menyebabkan lebih banyak investor yang akan memiliki saham perusahaan tersebut setelah perusahaan melakukan pengumuman pemecahan saham (post split). Kegiatan stock split dianggap mampu meningkatkan distribusi saham kepada banyak investor sehingga diharapkan mampu meningkatkan kepemilikan saham secara publik.

Dennis \& Strickland (1998) dalam penelitiannya tentang pengaruh dari pemecahan saham terhadap likuiditas saham dengan memperhatikan komposisi kepemilikan saham menemukan bahwa (1) turnover saham meningkat untuk saham yang level kepemilikan institusinya rendah dan relatif tidak berkurang untuk saham dengan kepemilikan institusi tinggi sebelum saham tersebut melakukan pengumuman pemecahan saham. Perusahaan dengan kepemilikan institusional rendah akan secara dramatis meningkat porsi kepemilikan institusionalnya setelah pemecahan saham dilakukan; (2) Perubahan likuiditas berhubungan dengan perubahan struktur kepemilikan saham sebagai akibat adanya pemecahan saham; (3) abnormal return sebagai akibat pemecahan saham berhubungan secara negatif dengan kepemilikan institusi sebelum pemecahan saham.

Dennis \& Strickland (1998) menyatakan bahwa ketidakmampuan penelitian terdahulu menjelaskan pengaruh pemecahan saham terhadap likuiditas saham karena belum mempertimbangkan tingkat kepemilikan saham oleh kelompok institusi sebelum peristiwa pemecahan saham 
terjadi. Lebih lanjut dijelaskan bahwa kepemilikan saham oleh institusi sebelum pemecahan saham secara signifikan mampu menjelaskan perubahan likuiditas yang diakibatkan oleh peristiwa pemecahan saham. Kepemilikan saham institusional secara signifikan berkontribusi secara besar terhadap volume perdagangan.

Penelitian stock split di Bursa Efek Indonesia memberikan hasil yang cenderung pada perubahan abnormal return dan juga transaksi perdagangan. Pengumuman pemecahan saham lebih cenderung direspon oleh para investor sehingga akan memberikan dampak return yang berbeda berkenaan dengan perubahan harga saham bukan pada volume perdagangan saham yang terjadi (Sariwulan, 2007; Lubis, 2010). Hasil ini mengindikasikan bahwa investor menduga ada kandungan informasi yang dapat diserap pasar berkenaan dengan kegiatan stock split tersebut. Inverstor merespon dengan secara membeli saham tersebut dan bersedia membayar harga saham tersebut secara lebih untuk mengantisipasi kandungan informasi yang terdapat dalam stock split.

Penelitian Khasanah (2007) tentang reaksi seputar stock split perusahaan menyatakan bahwa pengumuman stock split mempunyai kandungan informasi sehingga direspon oleh para pelaku pasar. Pengumuman stock split memiliki muatan informasi negatif, dan aktivitas stock split merupakan cara efektif untuk meningkatkan likuiditas saham. Hasil penelitian yang berbeda disampaikan oleh Haryanto \& Hermawan (2005) yang menyatakan bahwa stock split menyebabkan terdapat abnormal return yang memiliki perbedaan signifikan antara sebelum peristiwa dibandingkan dengan sesudah peristiwa. $\mathrm{Hal}$ ini menunjukkan bahwa pengumuman pemecahan saham memiliki muatan informasi yang positif.

Goyenko, Holden, \& Ukhov (2006) menyatakan bahwa kegiatan pemecahan saham akan berdampak pada peningkatan likuiditas perdagangan dalam jangka panjang. Hal ini relevan dengan trading range theory yang menyatakan bahwa stock split akan meningkatkan likuiditas perdagangan saham. Menurut teori ini, harga saham yang terlalu tinggi menyebabkan saham tersebut kurang aktif diperdagangkan. Dengan adanya stock split, harga saham menjadi tidak terlalu tinggi sehingga akan semakin banyak investor yang mampu bertransaksi, khususnya investor menengah dan investor kecil. Secara teori, semakin tinggi harga saham semakin rendah volume perdagangan saham yang terjadi, demikian pula sebaliknya. Dengan kata lain, stock split akan menata kembali harga saham pada rentang harga tertentu (optimal range). Adanya optimal range akan menciptakan pasar yang lebih luas. Jadi setelah stock split diharapkan volume perdagangan saham meningkat. Hal ini akan menyebabkan harga saham akan berubah seiring dengan perubahan permintaan dan penawaran saham. Harga saham yang cenderung lebih rendah akan menarik minat investor untuk membeli saham tersebut sehingga diharapkan harga saham akan terjangkau untuk para investor retail dan individual.

Perbedaan hasil penelitian tentang pengaruh stock split ini mendorong banyak penelitian terus dilakukan sehingga semakin memberikan hasil studi yang semakin 
lengkap dan mendalam berkenaan dengan faktor-faktor yang menyebabkan perbedaan hasil tersebut. Berdasarkan pertimbangan hal tersebut di atas, maka dalam penelitian ini diduga ada dampak yang ditimbulkan dari peristiwa stock split terhadap kegiatan perdagangan saham di pasar, dan terangkum dalam hipotesa penelitian. Dengan demikian, hipotesis pertama yang diajukan adalah terdapat perbedaan abnormal return dan likuiditas saham sebelum dan sesudah pengumuman stock split (Ha1)

Menurut Dennis \& Strickland (1998) dalam penelitiannya tentang pengaruh dari pemecahan saham terhadap likuiditas saham dengan memperhatikan komposisi kepemilikan saham menemukan bahwa (1) turnover saham meningkat untuk saham yang level kepemilikan institusi nya rendah dan relatif tidak berkurang untuk saham dengan kepemilikan institusi tinggi sebelum saham tersebut melakukan pengumuman pemecahan saham. Perusahaan dengan kepemilikan institusional rendah akan secara dramatis meningkat porsi kepemilikan institusionalnya setelah pemecahan saham dilakukan.(2) Perubahan likuiditas berhubungan dengan perubahan struktur kepemilikan saham sebagai akibat adanya pemecahan saham; (3) abnormal return sebagai akibat pemecahan saham berhubungan secara negatif dengan kepemilikan institusi sebelum pemecahan saham. Menurut Dennis \& Strickland (1998) ketidakmampuan penelitian terdahulu menjelaskan pengaruh pemecahan saham terhadap likuiditas saham sebagai akibat dari tidak dipertimbangkannya tingkatan kepemilikan saham oleh kelompok institusi sebelum peristiwa pemecahan saham terjadi. Lebih lanjut dijelaskan bahwa kepemilikan institusi sebelum pemecahan saham secara signifikan mampu menjelaskan perubahan likuiditas yang diakibatkan oleh peristiwa pemecahan saham karena kepemilikan saham institusional secara signifikan berkontribusi secara besar terhadap volume perdagangan. Jadi, hipotesis kedua yang diajukan adalah komposisi kepemilikan saham dan Perubahan komposisi sebagai akibat pemecahan saham berpengaruh terhadap likuiditas saham ( $\mathrm{Ha} 2)$.

\section{METODE}

Penelitian ini merupakan penelitian ex-post facto karena meneliti peristiwa yang telah terjadi dan mengidentifikasi faktor-faktor yang dapat menimbulkan kejadian tersebut Berdasarkan jenis data yang digunakan, penelitian ini dapat digolongkan sebagai penelitian kuantitatif. Penelitian ini juga bersifat event study dengan menggunakan peristiwa stock split sebagai event penelitian yang menjadi fokus penelitian berkenaan dengan hipotesis penelitian.

Penelitian ini dilakukan di Bursa Efek Indonesia (BEI) dengan objek penelitian berupa saham yang terdaftar di Bursa Efek Indonesia. Data yang digunakan merupakan data sekunder. Adapun data yang digunakan dari berbagai sumber data baik secara online maupun melalui galeri pasar modal. Periode penelitian adalah peristiwa stock split yang dilakukan dari tahun 2010 - 2015. Populasi dalam penelitian ini adalah semua perusahaan di Bursa Efek Jakarta yang melakukan pemecahan saham.

Metode pengambilan sampel penelitian ini menggunakan kriteria purposive sampling 
dengan menggunakan kriteria (1) Perusahaan yang melakukan pemecahan saham dari tahun 2010 - 2015; (2) Perusahaan yang memiliki data yang lengkap untuk kebutuhan analisis data secara statistik; (3) Perusahaan tidak melakukan company action yang berdekatan waktunya dengan kegiatan stock split.

Variabel terikat dalam penelitian ini adalah likuiditas saham.Variabel likuiditas menggunakan pengukuran sebagaimana yang digunakan Khasanah (2007) dan Haryanto \& Hermawan (2005) yaitu dengan trading volume activity (TVA). TVA diukur dengan menggunakan perhitungan volume perdagangan saham pada hari ke-t dibagi dengan jumlah keseluruhan saham yang beredar pada hari ke-t.

Variabel bebas dalam penelian ini adalah komposisi kepemilikan saham publik dan perubahan komposisi kepemilikan saham setelah peristiwa stock split. Pengukuran komposisi kepemilikan institusional mengacu pada definisi Dennis \& Strickland (1998) yang mendefinisikan komposisi kepemilikan saham institusional sebagai kepemilikan saham yang dipegang oleh institusi pada akhir kuarter dibagi dengan jumlah saham yang beredar pada akhir kuartal tersebut. Penelitian ini menggunakan data kepemilikan saham publik. Data komposisi saham publik diperoleh dari laporan keuangan yang dikeluarkan perusahaan pada periode pelaporan sebelum dan setelah peristiwa stock split terjadi. Ukuran variabel komposisi kepemilikan saham publik dalam penelitian ini menggunakan data persentase kepemilikan saham publik yang terdapat dalam laporan keuangan. Sedangkan pengukuran variabel perubahan komposisi saham publik dengan membandingkan struktur kepemilikan saham sebagai akibat peristiwa stock split.Variabel perubahan komposisi saham publik menggunakan variabel dummy dengan nilai dummy 0 (nol) untuk perusahaan yang komposisi saham publik tidak berubah atau turun, dan nilai 1 (satu) untuk perusahaan yang komposisi saham publik mengalami kenaikan. Penelitian ini menggunakan variabel kontrol berupa ukuran perusahaan (size). Ukuran perusahaan diukur dengan menggunakan logaritma natural dari nilai kapitalisasi pasar saham perusahaan tersebut. Nilai kapitalisasi pasar saham diukur pada periode $t+1$ sampai dengan $\mathrm{t}+10$ dan menggunakan nilai rata rata dari 10 hari periode pengukuran tersebut.

Variabel return saham digunakan dalam pengujian hipotesis pertama berkenaan dengan peristiwa stock split. Pengukuran return saham menggunakan return saham harian dari saham tersebut. Periode waktu pengukuran untuk return saham adalah 10 hari sebelum peristiwa stock split dan 10 hari setelah peristiwa.

Adapun perhitungan return harian:

$$
R_{i t}=\frac{\operatorname{Harga}_{t}-\operatorname{Harga}_{t-1}}{\operatorname{Harga}_{t-1}}
$$

$\mathrm{R}_{\mathrm{it}} \quad$ : Return saham i pada hari ke $\mathrm{t}$

Harga $t \quad$ : Harga saham i pada hari ke $t$ Harga t-1 : Harga saham i pada hari ke t- 1 Perhitungan abnormal return menggunakan metode market adjusted yang menggunakan return IHSG sebagai return pasar.

Metode pengujian untuk menguji hipotesis pertama (Ha1) penelitian ini menggunakan teknik analisis uji beda ratarata untuk sampel berpasangan (paired sample t-test). Pengujian hipotesis dilakukan 
selama 10 hari sebelum dan 10 hari sesudah peristiwa dengan menggunakan nilai cumulative abnormal return dan rerata trading volume activity periode 10 hari sebelum peristiwa dibandingkan dengan 10 hari setelah peristiwa. Uji beda rata-rata untuk sampel berpasangan (paired sample $t$ test) digunakan untuk menguji perbedaan rata rata abnormal return dan likuiditas saham sepuluh hari sebelum dan sepuluh hari sesudah peristiwa stock split.

Metode pengujian hipotesis kedua menggunakan persamaan regresi yang diadopsi dari Dennis \& Strickland (1998) dengan menggunakan variabel penelitian yang dipilih peneliti sesuai dengan karakteristik pasar modal Indonesia. Persamaan regresi dalam pengujian hipotesis kedua (Ha2) sebagai berikut di bawah ini:

TVA $=\propto+\beta_{1}$ Size $+\beta_{2}$ Institutional $+\beta_{3}$

Perubahan Institusional $+\varepsilon$

dimana: TVA adalah trading volume activity setelah pemecahan saham; Size adalah ukuran perusahaan, dan institutional adalah persentase kepemilikan saham oleh publik setelah pengumuman pemecahan saham, perubahan institusional merupakan dummy variable dengan nilai 1 untuk perusahaan yang mengalami perubahan persentase komposisi saham publik setelah stock split dan nilai 0 untuk yang tidak berubah.

Perhitungan variabel dependen trading volume activity (TVA) dalam penelitian ini menggunakan dua ukuran yaitu:

1. Rerata trading volume activity yang dihitung berdasarkan rata-ratanya selama periode 10 hari setelah kegiatan stock split,
2. Trading volume activity harian yang terjadi setelah kegiatan stock split. Adapun durasi waktu yang akan digunakan adalah $h+1, h+2$

\section{HASIL DAN PEMBAHASAN}

Perusahaan yang melakukan pemecahan saham selama periode tahun 2010 - 2015 sebanyak 48 perusahaan. Persebaran perusahan yang melakukan pemecahan saham berdasarkan tahun penelitian yaitu 5 perusahaan pada tahun 2010 (10,4\%), 11 perusahaan pada tahun 2011 (22,9\%), 17 perusahaan pada tahun 2012 (35,4\%), dan 11 perusahaan pada tahun 2013 (22,9\%), 2 perusahaan pada tahun 2014 (4,2\%) dan 2 perusahaan pada tahun 2015 (4,2\%).

Pengujian hipotesis pertama menggunakan metode paired sample $t$ test. Pengujian pertama dengan menggunakan data trading volume activity yang membandingkan mean trading volume activity 10 hari sebelum kejadian pengumuman dengan mean trading volume activity 10 hari sesudah pengumuman pemecahan saham. Pengujian kedua dengan menggunakan abnormal return saham. Pengujian dilakukan dengan membandingkan cumulative abnormal return (CAR) 10 hari sebelum peristiwa pengumuman dengan cumulative abnormal return (CAR) 10 hari setelah peristiwa pengumuman

Secara terperinci hasil pengujian hipotesis pertama dengan menggunakan data rerata volume transaksi perdagangan 10 hari sebelum peristiwa dibandingkan dengan 10 setelah peristiwa stock split tercantum dalam tabel 1. 
Tabel 1. Hasil pengujian pair sample $t$ test rerata volume aktivitas perdagangan sebelum dengan rerata volume perdagangan sesudah pemecahan saham

\begin{tabular}{|c|c|c|}
\hline & $\begin{array}{l}\text { TVA Sebelum } \\
\text { stock split }\end{array}$ & $\begin{array}{l}\text { TVA sesudah } \\
\text { stock split }\end{array}$ \\
\hline Rata-rata & 0,01779 & 0,00205 \\
\hline $\begin{array}{l}\text { T test } \\
\text { Sig (2 tail) }\end{array}$ & & \\
\hline
\end{tabular}

Tabel 1 menggambarkan rata-rata TVA sebelum dan sesudah pemecahan saham dengan nilai rata-rata TVA sebelum pemecahan saham 0,01779 dan rata-rata TVA sesudah pemecahan saham 0,00205. Tabel 1 memperlihatkan bahwa ada perbedaan antara rata-rata volume aktivitas perdagangan sebelum pemecahan saham dengan rata-rata volume aktivitas perdagangan saham setelah pemecahan saham. Hal ini diperlihatkan dari nilai t uji sebesar -3,785. Dengan melihat nilai signifikansi sebesar 0,000 memperlihatkan bahwa pengujian dengan menggunakan data rerata trading volume activity mendukung hipotesis Ha1 diterima.

Dari hasil pengujian hipotesis ini memberikan informasi bahwa pelaksanaan stock split yang dilakukan perusahaan memberikan pengaruh terhadap volume perdagangan saham yang terjadi setelah peristiwa tersebut terjadi yaitu selama periode penelitian ( 10 hari) Pelaku pasar merespon perisitiwa stock split sebagai peristiwa yang dapat menggerakkan perdagangan saham di pasar modal.

Pengujian kedua untuk hipotesis pertama (Ha1) dengan menggunakan comulative abnormal return (CAR) untuk menguji keberadaan informasi yang dihipotesiskan tertulis dalam tabel 2.

Tabel 2 menggambarkan cumulative abnormal return (CAR) sebelum dan sesudah pemecahan saham dengan nilai cumulative abnormal return (CAR) pemecahan saham 0,0329 dan cumulative abnormal return (CAR) sesudah pemecahan saham -0,1097. Tabel 2 memperlihatkan bahwa ada perbedaan antara cumulative abnormal return (CAR) saham sebelum pemecahan saham dengan cumulative abnormal return (CAR) saham setelah pemecahan saham. Hal ini diperlihatkan dari hasil pengujian yang menunjukkan nilai $t$ uji sebesar - 3,785. Dengan melihat nilai signifikansi sebesar 0,000 , hasil pengujian dengan menggunakan cumulative abnormal return (CAR) tersebut memperlihatkan bahwa hipotesis $\mathrm{Ha} 1$ diterima.

Tabel 2 Hasil pengujian pair sample t test cumulative abnormal return (CAR) sebelum dengan cumulative abnormal return (CAR) sesudah pemecahan saham

\begin{tabular}{|c|c|c|}
\hline & $\begin{array}{c}\text { CAR Sebelum } \\
\text { stock split }\end{array}$ & $\begin{array}{c}\text { CAR sesudah } \\
\text { stock split }\end{array}$ \\
\hline Rata-rata & 0,0329 & $-0,1097$ \\
\hline $\mathrm{T}$ test & & \\
\hline Sig (2 tail) & & \\
\hline
\end{tabular}


Tabel 3. ANOVA dalam model regresi menggunakan rerata trading volume activity sebagai variabel dependen

\begin{tabular}{lccc}
\hline & F test & & Sig (value) \\
\hline ANOVA & 1,024 & & 0,391 \\
\hline R & & 0,255 & \\
R Square & & 0,065 & \\
Adjusted R Square & & 0,002 & \\
Durbin Watson test & & 1,795 & \\
\hline
\end{tabular}

Dari hasil pengujian hipotesis ini memberikan informasi bahwa pelaksanaan stock split yang dilakukan perusahaan memberikan informasi kepada pasar yang direspon oleh pelaku pasar sehingga memberikan abnormal return setelah peristiwa tersebut terjadi yaitu selama periode penelitian (10 hari). Pelaku pasar merespon perisitiwa stock split sebagai peristiwa yang dapat menggerakkan perdagangan saham di pasar modal.

Pengujian hipotesis pertama yang secara statistik signifikan menunjukkan bahwa ada perbedaan abnormal return dan trading volume activity trading volume activity yang terjadi sebelum dibandingkan dengan setelah peristiwa. Stock split menjadi salah satu faktor pemicu para pelaku pasar untuk melakukan perdagangan secara lebih aktif. Hasil pengujian ini mendukung trading range theory yang menyatakan bahwa stock split akan meningkatkan likuiditas perdagangan saham. Harga saham yang terlalu tinggi menyebabkan saham tersebut kurang aktif diperdagangkan. Dengan adanya stock split, harga saham menjadi tidak terlalu tinggi sehingga akan semakin banyak investor yang mampu bertransaksi, khususnya investor menengah dan investor kecil. Stock split akan menata kembali harga saham pada rentang harga tertentu (optimal range). Adanya optimal range akan menciptakan pasar yang lebih luas. Hasil penelitian ini konsisten dengan penelitian-penelitian yang sudah dilakukan terlebih dahulu di Indonesia yang menunjukkan bahwa terdapat perbedaan likuiditas saham sebelum pemecahan saham dengan sesudah pemecahan saham seperti Fatmawati \& Asri (1999), Sutikno (2008), Puspitasari (2009) dan Khasanah (2007) yang menyatakan bahwa terdapat perbedaan likuiditas saham sebelum dan setelah pemecahan saham.

Hipotesis kedua berusaha meneliti pengaruh komposisi saham publik yang dimiliki perusahaan dan perubahan komposisi saham publik/privat dalam peristiwa stock split terhadap likuiditas saham yang diukur dengan menggunakan trading volume activity. Pengujian hipotesis kedua menggunakan pengukuran trading volume activity dengan dua pendekatan yang berbeda yaitu (1) rerata trading volume activity dengan periode pengamatan 10 hari setelah kegiatan stock split; dan (2) Trading volume activity harian untuk $\mathrm{h}+1, \mathrm{~h}+2$,

Pengujian hipotesis ( $\mathrm{Ha} 2$ ) yang pertama dengan menggunakan variabel dependen trading volume activity yang diukur dengan menggunakan rerata trading volume activity 10 hari setelah periode stock split terdapat dalam Tabel 3.

Hasil pengujian hipotesis kedua tentang pengaruh komposisi saham publik dan 
Tabel 4. Koefisien variabel independen dan uji t dengan rerata TVA $(h+1 s . d h+10)$

\begin{tabular}{lcccc}
\hline \multicolumn{1}{c}{ Variabel } & $\begin{array}{c}\text { Standardized } \\
\text { coefficient of Beta }\end{array}$ & T tes & Sig value & VIF test \\
\hline Konstanta & & 1,7366 & 0,089453 & \\
Size Perusahan & $-0,23910$ & $-1,5673$ & 0,124205 & 1,095519 \\
Komposisi saham publik & 0,16124 & 1,0752 & 0,288109 & 1,058429 \\
Dummy_perubahan & 0,00526 & $-0,0354$ & 0,971914 & 1,040040 \\
komposisi saham & & & & \\
\hline
\end{tabular}

perubahannya sebagai akibat kegiatan stock split terangkum dalam tabel 3 menunjukkan bahwa hasil uji model dengan menggunakan nilai uji $\mathrm{F}$ memperlihatkan nilai $F$ test sebesar 1,024 dengan nilai signifikansi sebesar 0,291. Hasil test ini memberikan informasi bahwa keberadaan variabel dependen tidak berhubungan dengan variabel independen. Hasil pengujian $\mathrm{F}$ test ini konsisten dengan hasil pengujian t test dalam model ini yang terangkum dalam tabel 4.

Hasil pengujian $t$ test tersebut memperlihatkan bahwa variabel independen yang digunakan dalam model regresi tersebut tidak ada yang signifikan. Variabel ukuran perusahaan sebagai variabel kontrol untuk mengontrol pengaruh dari ukuran perusahaan besar dan kecil secara statistik tidak berpengaruh terhadap likuiditas saham yang diukur dengan trading volume activity.

Pengujian hipotesis penelitian berkaitan dengan komposisi saham yang dimiliki oleh publik maupun perubahan perubahan komposisi saham setelah peristiwa stock split juga tidak memberikan hasil penelitian yang signifikan. Hal ini bisa diketahui dari hasil uji t test untuk variabel independen komposisi saham publik dan variabel indenden dummy perubahan komposisi saham. Hasil uji $t$ kedua variabel independen tersebut menunjukkan nilai signifikansi komposisi saham publik 0,29 dan 0,97 untuk dummy perubahan komposisi saham, sehingga secara uji statistik menyatakan bahwa variabel komposisi saham publik dan juga variabel perubahan komposisi saham tidak berpengaruh terhadap likuiditas saham yang diukur dengan trading volume activity.

Pendekatan kedua dalam pengujian hipotesis kedua ( $\mathrm{Ha} 2)$ menggunakan variabel dependen trading volume activity yang diukur dengan menggunakan data harian yang akan diuji untuk dampak stock split $\mathrm{h}+1$, dan pengujian untuk dampak stock split sampai dengan $h+2$. Pengujian ini menggunakan data harian saham sehingga diharapkan mampu mengetahui perubahan likuiditas pada titik waktu setelah kejadian $(h+1, h+2)$. Hasil pengujian regresi dengan menggunakan dua periode rentang data yang berbeda $(\mathrm{h}+1$; dan $\mathrm{H}+1$ s.d. $\mathrm{h}+2)$ terangkum dalam tabel 5 .

Hasil pengujian dengan menggunakan data harian trading volume activity baik untuk periode $\mathrm{h}+1$ dan $\mathrm{h}+1 \mathrm{~s} . \mathrm{d} \mathrm{h}+2$ konsisten dengan hasil pengujian hipotesis dengan menggunakan rerata trading volume activity sebagaimana tabel 5 . Hasil uji $F$ baik untuk TVA $\mathrm{h}+1$ maupun TVA s.d $\mathrm{h}+2$ secara statistik tidak signifikan dengan nilai signifikansi 0,65 dan untuk TVA $h+1$ s.d $h+2$ sebesar 0,359. Hasil pengujian ini juga memperlihatkan 
Tabel 5. ANOVA dalam model regresi menggunakan data harian trading volume activity $h+1$; dan $\mathrm{H}+1$ s.d. $\mathrm{h}+2$ sebagai variabel dependen

\begin{tabular}{lcccc}
\hline \multirow{2}{*}{ Keterangan } & \multicolumn{2}{c}{ Data $\mathrm{h}+1$} & \multicolumn{2}{c}{ Data $\mathrm{h}+1 \mathrm{s.d} \mathrm{h}+2$} \\
\cline { 2 - 4 } & $\mathrm{F}$ test & Sig (value) & $\mathrm{F}$ test & Sig (value) \\
\hline ANOVA & 0,551171 & 0,650163 & 1,085354 & 0,359480 \\
\hline R & 0,194623 & 0,186856 \\
R Square & 0,037878 & 0,034915 \\
Adjusted R Square & $-0,030845$ & 0,002746 \\
Durbin Watson test & 2,040958 & 1,299818 \\
\hline
\end{tabular}

bahwa likuiditas saham perusahaan setelah peristiwa stock split tidak dipengaruhi oleh ukuran perusahaan, komposisi saham publik yang terdapat dalam perusahaan tersebut, maupun perubahan komposisi saham publik yang terjadi sebagai akibat peristiwa stock split. Variabel ukuran perusahaan sebagai variabel kontrol yang digunakan tidak berpengaruh signifikan dalam membedakan ukuran perusahaan besar dan kecil. Variabel komposisi saham publik dan perubahan komposisi saham publik ternyata juga tidak memberikan pengaruh bagi likuiditas saham setelah peristiwa stock split.

Pengujian secarah lebih lanjut dengan memperhatikan hasil uji $t$ untuk setiap variabel independen yang digunakan dalam persamaan regresi tersebut. Hasil uji $t$ dengan dua periode pengujian yang berbeda terangkum dalam tabel 6 dan tabel 7 .

Hasil uji t dalam tabel 6 menunjukkan bahwa variabel independen yang digunakan baik variabel kontrol (ukuran perusahaan) maupun variabel pengujian hipotesis (komposisi saham publik dan perubahannya) tidak memiliki pengaruh signifikan terhadap likuiditas saham. Hasil ini konsisten dengan hasil pengujian dengan menggunakan data rerata trading volume activity.

Pengujian hipotesis dengan menggunakan periode $\mathrm{H}+1$ dan $\mathrm{H}+2$ memberikan hasil yang sedikit berbeda dengan hasil pengujian sebelumnya ( rerata trading volume activity; dan periode $\mathrm{H}+1$ ). Hasil pengujian dalam Tabel 7 menunjukkan bahwa variabel kontrol (ukuran perusahaan) secara uji t memiliki significant value sebesar 0,07 sehingga dianggap memiliki pengaruh terhadap likuiditas saham dalam rentang derajat kepercayaan $10 \%$, dan memiliki hubungan yang negatif. Hasil lainnya berkaitan dengan variabel penelitian hipotesis (komposisi saham dan perubahannya) menunjukkan hasil yang tidak signifikan berpengaruh terhadap likuiditas saham dan hasil ini konsisten

Tabel 6. Koefisien variabel independen dan uji t untuk periode TVA $(h+1)$

\begin{tabular}{lcccc}
\hline \multicolumn{1}{c}{ Variabel } & $\begin{array}{c}\text { Standardized } \\
\text { coefficient of Beta }\end{array}$ & T tes & Sig value & VIF test \\
\hline Konstanta & & 1,496592 & 0,141977 & \\
Size Perusahan & $-0,200017$ & $-1,249343$ & 0,218458 & 1,118893 \\
Komposisi saham publik & 0,010615 & 0,067502 & 0,946503 & 1,079590 \\
Dummy_perubahan & $-0,055760$ & $-0,360695$ & 0,720136 & 1,043235 \\
komposisi saham & & & & \\
\hline
\end{tabular}


dengan hasil pengujian dengan interval data yang lain.

Hasil pengujian yang dilakukan menunjukkan bahwa komposisi saham publik tidak memiliki pengaruh terhadap likuiditas saham yang terjadi setelah peristiwa stock split. Hasil pengujian ini konsisten baik untuk data rerata 10 hari setelah stock split, maupun menggunakan data harian setelah stock split. Likuiditas perdagangan saham ternyata tidak dipengaruhi oleh komposisi saham publik yang ada dalam kepemilikan saham tersebut. Komposisi saham publik yang besar ternyata tidak menyebabkan saham tersebut menjadi lebih aktif diperdagangkan. Hasil penelitian ini menunjukkan bahwa kebijakan stock split tidak serta merta mendorong terjadinya perubahan komposisi kepemilikan saham publik. Pelaku pasar modal di Indonesia tidak mempertimbangkan komposisi saham yang sebagai salah satu faktor yang mempengaruhi likuiditas perdagangan saham.

Hasil pengujian hipotesis kedua ini tidak sesuai dengan penelitian Dennis \& Strickland (1998) yang menyatakan kepemilikan institusi sebelum pemecahan saham secara signifikan mampu menjelaskan perubahan likuiditas yang diakibatkan oleh peristiwa pemecahan saham karena kepemilikan saham institusional secara signifikan berkontribusi secara besar terhadap volume perdagangan.

\section{SIMPULAN}

Berdasarkan hasil penelitian yang telah dilakukan dan hasil uji hipotesis menunjukkan bahwa pemecahan saham merupakan suatu kejadian yang mengandung informasi yang akan berpengaruh terhadap return saham dan likuiditas saham yang diukur dengan trading volume activity. Kegiatan stock split mampu mendorong investor untuk lebih aktif melakukan trasnsaksi perdangangan. Pelaku pasar modal merespon kegiatan stock split dengan ekspektasi return yang lebih (abnormal return) dibandingkan dengan pergerakan return pasar. Investor juga merespon peristiwa tersebut sehingga terjadi perbedaan aktivitas volume perdagangan dibandingkan dengan periode sebelum stock split.

Pengujian hipotesis kedua menunjukkan bahwa komposisi kepemilikan saham publik dalam suatu perusahaan tidak memberikan pengaruh terhadap likuiditas perdagangan saham. Likuiditas saham yang diukur dengan trading volume activity tidak ada keterkaitannya dengan komposisi saham publik yang terdapat dalam perusahaan tersebut. Perusahaan dengan komposisi saham publik yang tinggi/besar, tidak serta Tabel 7 Koefisien variabel independen dan uji t untuk periode TVA $(h+1$ dan $h+2)$

\begin{tabular}{lcccc}
\hline \multicolumn{1}{c}{ Variabel } & $\begin{array}{c}\text { Standardized } \\
\text { coefficient of Beta }\end{array}$ & T tes & Sig value & VIF test \\
\hline Konstanta & & 2,143382 & 0,034780 & \\
Size Perusahan & $-0,195331$ & $-1,793008$ & 0,076331 & 1,106768 \\
Komposisi saham publik & 0,043047 & 0,402287 & 0,688427 & 1,067805 \\
Dummy_perubahan & $-0,058260$ & $-0,551059$ & 0,582959 & 1,042383 \\
komposisi saham & & & & \\
\hline
\end{tabular}


merta meningkatkan likuiditas perdagangan sahamnya. Hasil pengujian ini tidak konsisten dengan hasil penelitian Dennis \& Strickland (1998) berkenaan dengan keberadaan komposisi kepemilikan saham publik yang memiliki pengaruh terhadap likuiditas perdagangan saham. Pengujian hipotesis kedua juga menunjukkan bahwa perubahan komposisi kepemilikan saham publik juga tidak berpengaruh terhadap likuiditas perdagangan saham. Peristiwa stock split tidak menjadikan pelaku pasar secara agresif melakukan pembelian saham. Pemilik saham secara privat juga tidak melepaskan kepemilikan sahamnya berkenaan dengan peristiwa stock split.

Penelitian ini masih banyak memiliki keterbatasan sehingga masih banyak ruang untuk penelitian lanjutan yang lebih mendalam dan mampu menjelaskan fenomena stock split terhadap likuiditas saham. Perlu mempertimbangkan pemilihan alat ukur likuiditas yang dapat secara menyeluruh menangkap kandungan informasi dari kejadian stock split. Hal ini perlu dilakukan sehingga dapat digunakan untuk membandingkan berbagai ukuran likuiditas untuk mengetahui konsistensi hasil penelitian. Pengujian hipotesis kedua yang belum signifikan memperlihatkan bahwa komposisi saham publik tidak memiliki pengaruh terhadap likuiditas saham. Hal ini perlu dikaji ulang pemilihan proksi yang lebih tepat dan juga periode pengujian yang tidak hanya menekankan pada pengujian pada peristiwa tertentu.

\section{DAFTAR PUSTAKA}

Anggraini, W. \& Jogiyanto, H.M. (2000). Penelitian Tentang Informasi Laba dan Dividen Kas yang Dibawa Oleh Pengumuman Pemecahan Saham. Jurnal Bisnis dan Akuntansi, 2(1), 1-12.

Dennis, P.J. \& Strickland, D. (1998). The Effect of Stock Splits on Llquidity: Evidence from Shareholder Ownership Compositition. Diakses dari https://papers.ssrn.com/ sol3/papers.cfm?abstract_id=93658.

Fatmawati, S. \& Asri, M. (1999). Pengaruh Stock split Terhadap Likuiditas Saham Yang Diukur Dengan Besarnya Bid-Ask Spread di Bursa Efek Jakarta. Jurnal Riset Akuntansi, 14(4), 263-277.

Goyenko, R., Holden, C.W. \& Ukhov, A. (2006). Do Stock Splits Improve Liquidity? Working Paper. Diakses dari https://papers.ssrn.com/sol3/papers.cf m?abstract_id=675923.

Grinblatt, M.S., Masulis, R.W. \& Titman, S. (1984). The Valuation Effects of Stock Splits and Stock Dividends. Journal of Financial Economics, 13(4), 461-490.

Haryanto \& Hermawan W.D. (2005). Pengaruh Pemecahan Saham Terhadap Likuiditas dan Abnormal Return Saham Perusahaan di Bursa Efek Jakarta. Buletin Ekonomi, 3(3), 209-228.

Khasanah, N. (2007). Reaksi Pasar Seputar Pengumuman Stock Split. Skripsi. Universitas Negeri Yogyakarta.

Lin, J.C., Yu, W., \& Singh, A.K. (2008). Stock Splits and The Trading Speed Improvement Hypothesis. Diakses dari https://papers.ssrn.com/sol3/papers.cf m?abstract_id=1108392.

Lubis, W.S. (2010) Pengaruh Pemecahan Saham (Stock Split) Terhadap Perubahan Harga Saham dan Likuiditas Saham Pada Perusahaan Manufaktur yang Terdaftar di Bursa Efek Indonesia. Skripsi. Universitas Sumatera Utara. Diakses dari 
http://repository.usu.ac.id/handle/1234 56789/17980

Margaretha, F. (2003). Tinjauan Persepsi Manajemen Terhadap Struktur Modal Perusahaan Go Public. Media Riset Bisnis dan Manajemen, 3, 98-115.

Puspitasari, N.V.K. (2009). Analisis Perbedaan Likuiditas Dan Volume Perdagangan Saham Sebelum Dan Sesudah Stock Split Di Bursa Efek Indonesia. Skripsi Universitas Muhammadiyah Surakarta. Diakses dari http://etd.eprints.ums. ac.id/2998/
Sariwulan, T. (2007). Pengaruh Stock Split Terhadap Likuiditas Saham. Jurnal Trikonomika, 6(1).

Sukardi. (2000). Reaksi Pasar Terhadap Stock Split. Jurnal Aplikasi Bisnis, 1(1)

Sutikno, D. (2008). Pengaruh Stock Split: Analisis Likuiditas Saham di Bursa Efek Jakarta. Skripsi. Universitas Muhammadiyah Surakarta. Diakses dari http://eprints.ums.ac.id/2024/

Sutrisno, W., Susilowati, S., \& Yuniartha, F. (2000). Pengaruh Stock Split Terhadap Likuiditas dan Return Saham di Bursa Efek Jakarta. Jurnal Manajemen dan Kewirausahaan, 2(2), 1-13. 